\title{
Galilee Blooming: First palynological and archaeological data from an Early Byzantine Cistern at Horvat Kur
}

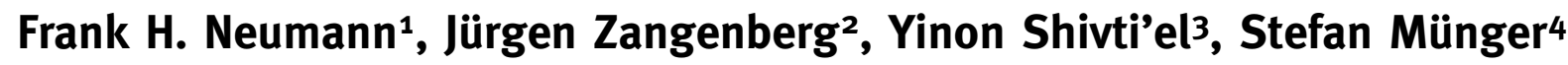

${ }^{1}$ Forschungsstelle für Paläobotanik, am Geologisch-Paläontologischen Institut, Westfälische WilhelmsUniversität Münster, Münster, Germany, ${ }^{2}$ Universiteit Leiden, Instituut voor Religiestudies, Leiden, The Netherlands, ${ }^{3}$ Zefat Academic College, D.N. Hevel Korazim, Zefat, Israel, ${ }^{4}$ Universität Bern, Institut für Judaistik, Bern, Switzerland

Preliminary archaeological and palynological results are presented from an early Byzantine cistern of the village Horvat Kur in eastern Lower Galilee/Israel. The rural site was settled from the Hellenistic until the Early Arab period, its synagogue was constructed shortly after $425 \mathrm{AD}$ and renovated sometimes during the 2 nd half of the 6th century $A D$. It was abandoned probably as a consequence of the earthquake of 749 AD. The intact and properly sealed cistern contained complete or fully restorable pottery. Two cooking pots from the early 5th century AD comprised sediments which was sampled for palynological purposes. Both samples, as well as a sample from the soil beneath one of the pots and a modern surface sample from the site, revealed well preserved palynomorphs in comparably high concentration showing a great potential of the cistern as a pollen archive. The pollen content points to an open, grassy semiarid landscape with an apparent scarcity of cultivars and trees in the vicinity of the site and an abundance of herbs, especially Asteraceae, which are still commonly found in modern regional vegetation.

Keywords: Palynology, Paleoecology, Geoarchaeology, Early Byzantine, Cistern, Galilee

\section{Introduction}

The site and the purpose of this study

Following preparatory explorations in 2007, 2008 and 2009, Kinneret Regional Project (KRP) (www.kin neret-excavations.org) conducted full-scale excavations on Horvat Kur, a rural site of ca. 3 ha located in the hills of Eastern Lower Galilee $2 \mathrm{~km}$ west of Lake Tiberias, in 2010, 2011 and 2012 Münger et al. 2009; Zangenberg 2010; Zangenberg et al. 2010; Zangenberg et al. 2011). During these activities remains of a village, agricultural installations such as water channels, wine presses or cisterns, and other elements of the surrounding rural infrastructure (e.g. graves) were detected as well as sections of two domestic houses and a synagogue, both dating to the 5th through 8th century AD. Pottery from fills indicates that the site was inhabited at least from the late 1st century BC onwards (note that there are also minute traces of earlier habitation during the Bronze- and Iron Ages). Features like broken thresholds and fallen walls suggest that the village

Correspondence to: Frank Neumann, Forschungsstelle für Paläobotanik am Geologisch-Paläontologischen Institut, Westfälische WilhelmsUniversität Münster, Heisenbergstrasse 2, 48149 Münster, Germany. Email: fneum_01@uni-muenster.de was destroyed by an earthquake. A date in the middle of the 8th century AD is suggested by the stratigraphy, all in all pointing to the devastating earthquake of 749 (Tsafrir and Foerster 1992). Limited activities at the site during the Early Islamic and Medieval periods are traceable as well (Fig. 1).

Explorations were carried out under the auspices of the Universities of Leiden, Bern and Helsinki, Wofford College (USA) and in cooperation with Haifa University, the Israel Antiquities Authority, the Deutsche Verein zur Erforschung Palästinas and the Hebrew University laboratories. The expedition was directed by Jürgen Zangenberg (Leiden) in cooperation with Stefan Münger (Bern), Byron McCane (Wofford College) and Raimo Hakola (Helsinki).

The main goals of KRP's activities on Horvat Kur are to collect detailed information on the structure, livelihood and history of a rural site in the Galilean hinterland, explore its cultural connections to the wider Mediterranean world and investigate the relationship between natural environment and settlement structure and history.

Consequently, palaeoenvironmental research plays an important role next to conventional surveys and excavations in and around the ancient village (cf. 


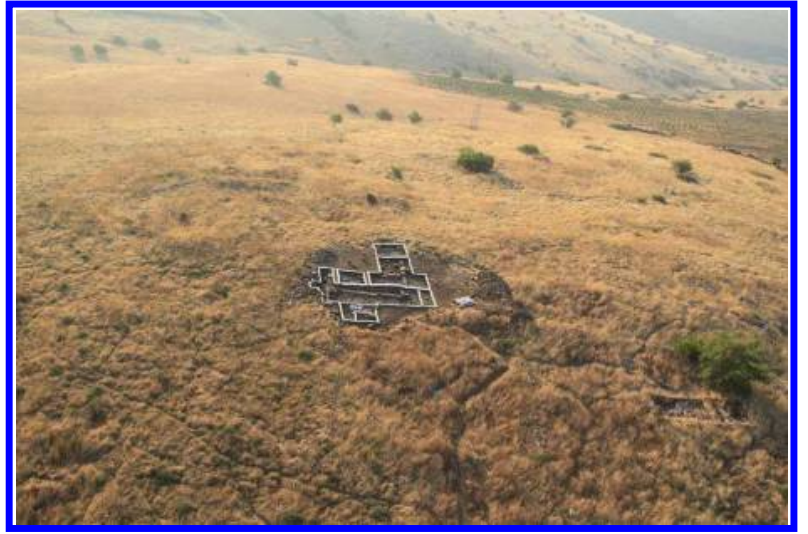

Figure 1 Aerial view of Horvat Kur looking East. In centre left the excavation area of the public building, to the right excavated remains of domestic structures. Situation at the end of the 2011 season (@ Skyview and Kinneret Regional Project).

Zangenberg et al. 2010). The long-term goals of the project's palaeoenvironmental component are to set up a diachronic model of the phytogeography, the historical climate and ecology on the northwestern shore of the Lake of Galilee and to correlate it with archaeological evidence of settlement history and everyday life focusing on the extent of human intervention, e.g. agriculture, onto local phytoecology and the use of natural resources in the southern Levant (Dincauze 2004, 345).

Together with palaeozoological and archaeobotanical data, palynological data are an important source of information for broader palaeoecological research. So far, questions of natural resources, climate and agriculture in the ancient Galilee have often been treated on the basis of ancient literary data (e.g. Leibner 2009, 11-14). Though sometimes remarkably detailed, literary data are necessarily selective and formed by their historical context and cannot provide a secure basis for a systematic reconstruction of the natural conditions of everyday life in rural Eastern Galilee.

Palynological data covering the HellenisticByzantine period are available from Lake Tiberias (Baruch 1986, 1990). For the time period covered by the settlement of Horvat Kur, especially the Hellenistic to Byzantine periods, the Lake Tiberias record gives the picture of an intensely cultivated region in the surroundings of the Lake. Olea pollen increases sharply, pollen of Vitis, Juglans and Ceratonia are abundant. In contrast percentages of both Quercus and Pistacia drop (Baruch 1986), probably as a result of enhanced wood cutting. A similar situation is observed at the crater lake of Birkat Ram on the northern Golan Heights, where a pollen record shows a detailed picture of the regional vegetation development during the above period (Schwab et al. 2004; Neumann et al. 2007b, Fig. 1). Here too, peak values of Olea, Vitis, Juglans and
Ceratonia siliqua mark intensive cultivation. Cupressus and Pinus both reach high percentages and might have been planted for commercial and/or ornamental purposes (Neumann et al. 2007b).

In a pollen diagram of the Huleh basin a wave of olive cultivation marks the Hellenistic-Byzantine period but seems to extend even to the Early Arab era (see Fig. 2, Baruch and Bottema 1999; van Zeist et al. 2009). This phenomenon of high Olea values is also observed in other pollen diagrams of the region, e.g. at the Dead Sea (Baruch 1990, 1993, 1994; Heim et al. 1997; Neumann et al. 2007a, 2009, 2010a, b; Leroy 2010; Litt et al. 2012). Most archives provide a more regional picture of vegetation change although local trends, e.g. along the western shore of the Dead Sea, are obvious (Neumann et al. 2010b). Small

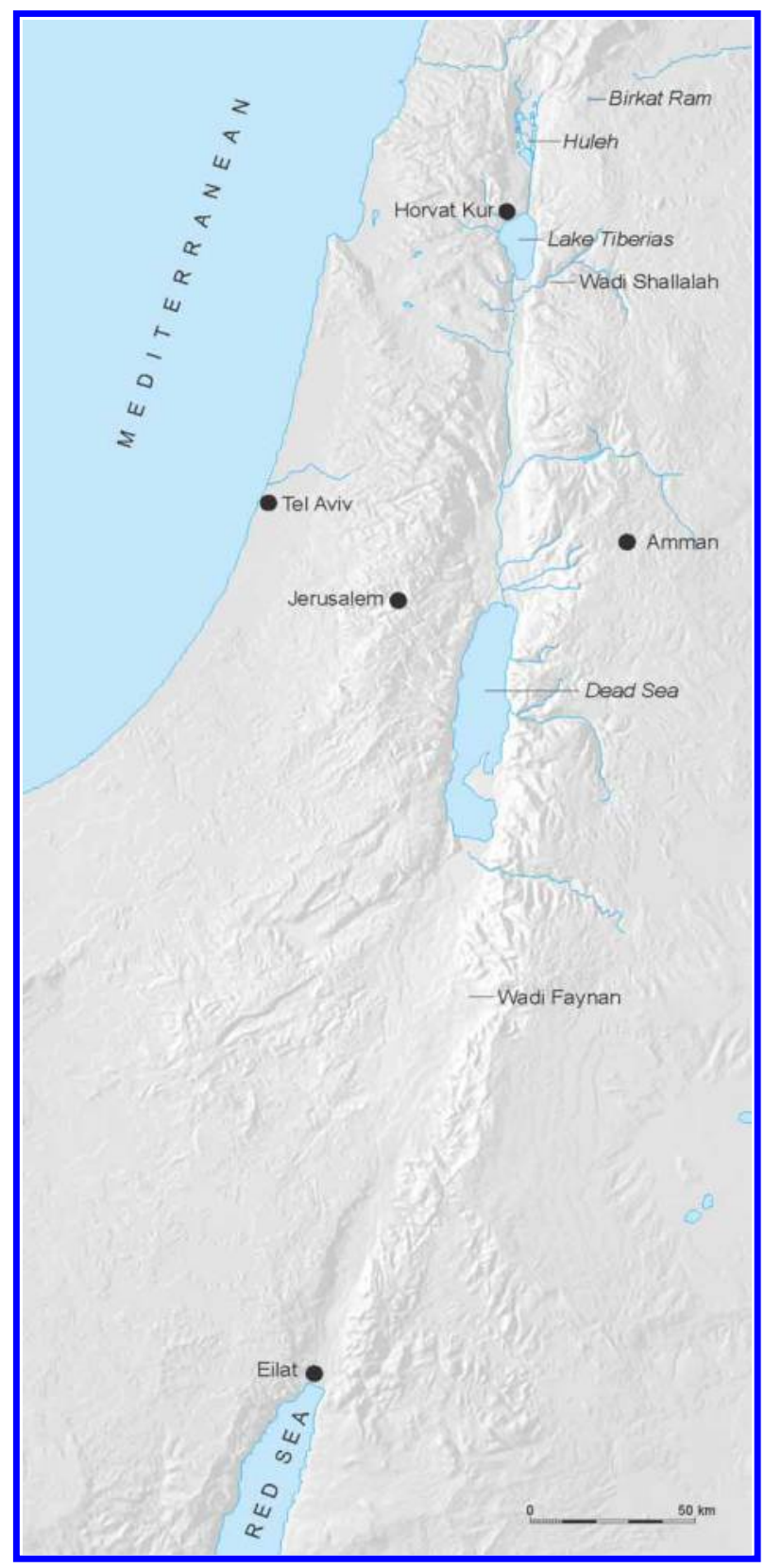

Figure 2 Map of the southern Levante showing locations mentioned in text and study site. 
wetlands, which might give a more local picture, are scarce in the Southern Levant and rarely exploited for palynological purposes (Galili and WeinsteinEvron 1985; Kadosh et al. 2004). From arid central Jordan, fluvial sediments in the Wadi Faynan allow a paleoenvironmental reconstruction for the Holocene and give evidence of greater precipitation during the Roman-Byzantine period (Hunt et al. 2004, 2007). Other alluvial archives, such as Wadi Shallalah ca. $40 \mathrm{~km}$ to the southwest of Lake Tiberias, bear palynomorphs from the Holocene although time resolution is often low (Cordova 2007).

\section{Objectives}

- The current study presents preliminary palynological data of sediment samples taken from a Byzantine cistern below the synagogue of Horvat Kur found during the excavation campaign in 2011 in comparison to palynological results of a modern surface sample taken at the site which reflects current vegetation. This allows a tentative comparison between local vegetation during the Byzantine period and modern times.

- Local palynological studies from the Galilee highlands have not been undertaken until now. Existing studies from Lake of Galilee, Birkat Ram and the Huleh swamps (Fig. 2) give a regional picture. A cistern has a small catchment with a radius of $<1 \mathrm{~km}$ and is suited to reflect local vegetation (van Haaster 2009). These data, although hampered by a low sample number, will provide a glimpse of the local vegetation, e.g. the degree of forest cover, and agricultural activities during the Byzantine period at Horvat Kur.

- We discuss problems of differential pollen preservation and transport in archaeological deposits and test the potential of the site as an archive for palaeoecological information. Those observations will be useful for further palynological studies at this and similar sites elsewhere.

\section{Methodological remarks on palynological findings in archaeological contexts in the light of different levels of pollen preservation}

Usually lacustrine sediments are preferred in palaeoeological studies due to excellent pollen preservation, but research was extended into archaeological sites which allowed more precise temporal control and an immediate comparison to the archaeological site and its environment (Hevly 1981). The palynological analysis of samples from living floors of buildings or stratigraphical sequences at archaeological sites in the Southern Levant is often not satisfying although tentative conclusions are possible (Horowitz 1988-1989; Hussey 1991; Warnock and Pendleton 1995; Schoenwetter and Geyer 2000). Sediments from cisterns, which reflect the vegetation in a perimeter of $600-800 \mathrm{~m}$, are often the only source of humid soil conservation in arid regions and allow reconstructions of the local agriculture and landscape development (Jacomet and Kreuz 1999, van Geel et al. 2003; van Haaster 2009). Cisterns were regularly cleaned during the period of use and sediments were deposited only after abandonment. Sediment layers can be divided into humid soil, affected by groundwater and often containing pollen, and dry soil where palynomorphs are normally destroyed by oxidation (destruction of sporopollenin building up the pollen wall) (Jacomet and Kreuz 1999, Stobbe 2009). High percentages of indeterminant palynomorphs, usually $>50 \%$, and low pollen concentration are signs of differential preservation, and general loss of pollen grains is due to oxidation, biological agents such as bacteria and phycomycete fungi, and high pH (Bryant et al. 1994, Bryant and Holloway 1996). Those processes including the vertical transport of palynomorphs through sediments via water (downwash) or by animal activity (bioturbation) are comparable to processes observed in terrestrial soils (Dimbleby 1961; Davidson et al. 1999; Gavin and Brubaker 1999). Consequently, the pollen concentration in archaeological contexts, especially in dry soils in arid regions, is often too low to achieve a precise portrait of the vegetation, the record is usually greatly influenced by anthropogenic disturbances and alteration of palynomorphs has often led to overrepresentation of more resistant pollen types (Fish 1989, see references in Lebreton et al. 2010). Poor, respectively differential pollen preservation may lead to the accumulation of certain pollen types, e.g., Cichorioideae, especially under dry climatic conditions (Weinstein-Evron and Chaim 1989; Weinstein-Evron 1994; compare Bottema 1975). Taphonomical studies on different pollen and sporetypes have shown that Cichorioideae pollen were more resistant to decay than other pollen-types (Havinga 1984). Consequently, this pollen-type is supposedly over-represented, e.g., in pollen spectra from archaeological sites (Bottema 1975), although more recent studies on the oxidation of different pollen types underline that oxidation might not be the only taphonomical process involved since Cichorioideae pollen do not appear to be more resistant than other experimentally tested pollen types (Lebreton et al. 2010). Lebreton et al. (2010) point out that, due to their unique morphology, pollen of Cichorioideae is simply less easy to confuse with other pollen types even after alteration. On the other hand, Cichorioideae and Tubuliflorae are also rather resistant and similarly typical open land indicators (Neumann et al. 2007a, b). Laboratory experiments by Lebreton et al. (2010) showed that certain pollen types, e.g. Caryophyllaceae and Pinus, are more vulnerable to oxidation and might be underrepresented 
in pollen spectra. Additionally, there is the problem of contamination by modern pollen entering ancient sediments. This can, at least partly, be avoided by careful withdrawal and storage of samples including cleaning of tools with water.

The majority of pollen found in man-made structures with small openings, e.g. cisterns as in the current case, is primarily transported by wind, but also erosion, anthropogenic activities, leaf litter, insects, snails and rodents (Hevly 1981; Jacomet and Kreuz 1999) although transport by water/ runoff plays a major role. According to Hevly (1981), sediments in cisterns, open only during a certain period of occupation and sealed for centuries, often yield low pollen concentrations. In conclusion, although palynology is a major tool in the reconstruction of palaeoenvironments, the above caveats need to be kept in mind when interpreting the following results.

\section{The Study Area}

\section{Location, morphology and geology}

The village of Horvat Kur is located on a hill $2 \mathrm{~km}$ west of Tel Kinrot, in the midst of fertile plains on a high-plateau north of Wadi Amud close to Lake Tiberias (ه $18.07 \mathrm{~m}$ asl; $\quad+32^{\circ} 53^{\prime} 5.91^{\prime \prime} /+$ 3532'14.09" WGS84; 250549/754541 NIG; Figs. 1-3). The maximum size of the village was ca. 3 ha as indicated by still visible architecture and habitational debris as observed in surface surveys.

The region is characterised by massive karstic limestones of the Bar Kokhba Formation which was deposited during the middle Eocene (Fig. 4: ebk; Michelson et al. 1987; Sneh et al. 1998; Sneh 2008). The cistern was dug into this limestone. Miocene Huqoq conglomerates appear $400 \mathrm{~m}$ to the south of Horvat Kur (Sneh 2008). The Pliocene Bira and Gesher Formations appear to the south of Ginnosar (Michelson et al. 1987; Sneh et al. 1998).

To the east and southwest of the site Pliocene Cover Basalts are forming a chain of prominent hills (Michelson et al. 1987; Sneh et al. 1998; Sneh 2008; Fig. 4). These basalts are comparable to those found on the eastern side of the lake. Horvat Kur is covered by basalt rock that have been washed down from the Korazim plateau. Both basalt and limestone are used as building material in the synagogue and the village. The surroundings of Horvat Kur are characterised by graben faults characteristic for the western flank of the Tiberias-Huleh graben system. Along slopes and in valleys, Holocene sediments, e.g., alluvial gravel, sand and clay, are deposited. A small plain to the west of the site is still now used for the cultivation of crops.

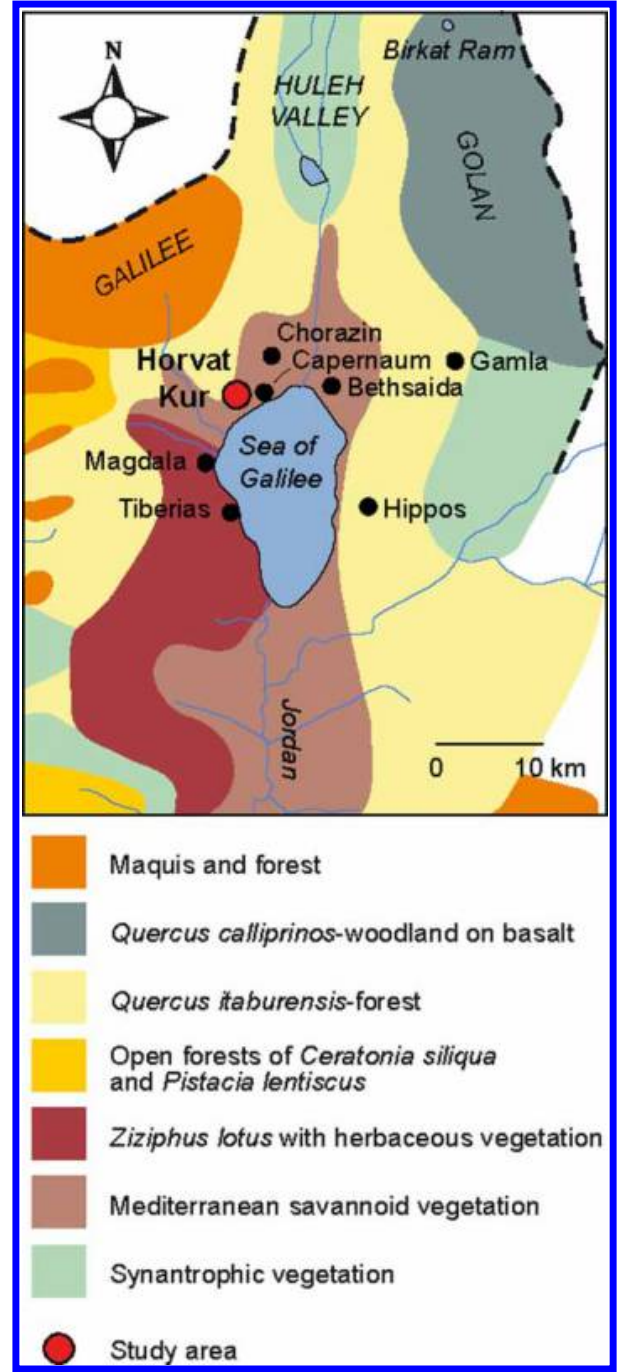

Figure 3 Vegetation map of Galilee after Danin (1999), location of important sites, including study area.

\section{Climate and vegetation}

The landscape around Horvat Kur is characterised by a Mediterranean climate with hot and dry summers and moist, warm winters. Rainfall increases with altitude and decreases from North to South from about 1000 to $450 \mathrm{~mm} /$ year (Baruch 1986; Cerda 1998). Across Lake Tiberias rainfall is about $400 \mathrm{~mm}$ /year. The rainy season spans from October to May with a peak between December and February (Baruch 1986). At Karei Deshe close to Horvat Kur precipitation is around $567 \mathrm{~mm} /$ year (Golodets et al. 2011).

Consequently, vegetation is well adapted to seasonal drought (Cerda 1998). Several biomes can be observed in Lower Galilee and the Golan heights (we follow Danin 1999, Fig. 3). According to Baruch (1986), the Mediterranean Savannoid Zone, in which Horvat Kur is situated, occupies a belt between 0 and $-200 \mathrm{~m}$ stretching around the shore of the Lake and into the central Jordan Rift Valley. Ziziphus lotus characterises open savanna-like grasslands with Triticum, Avena and Hordeum and other grasses. A plant survey at Karei Deshe (i.e. part of the northern 


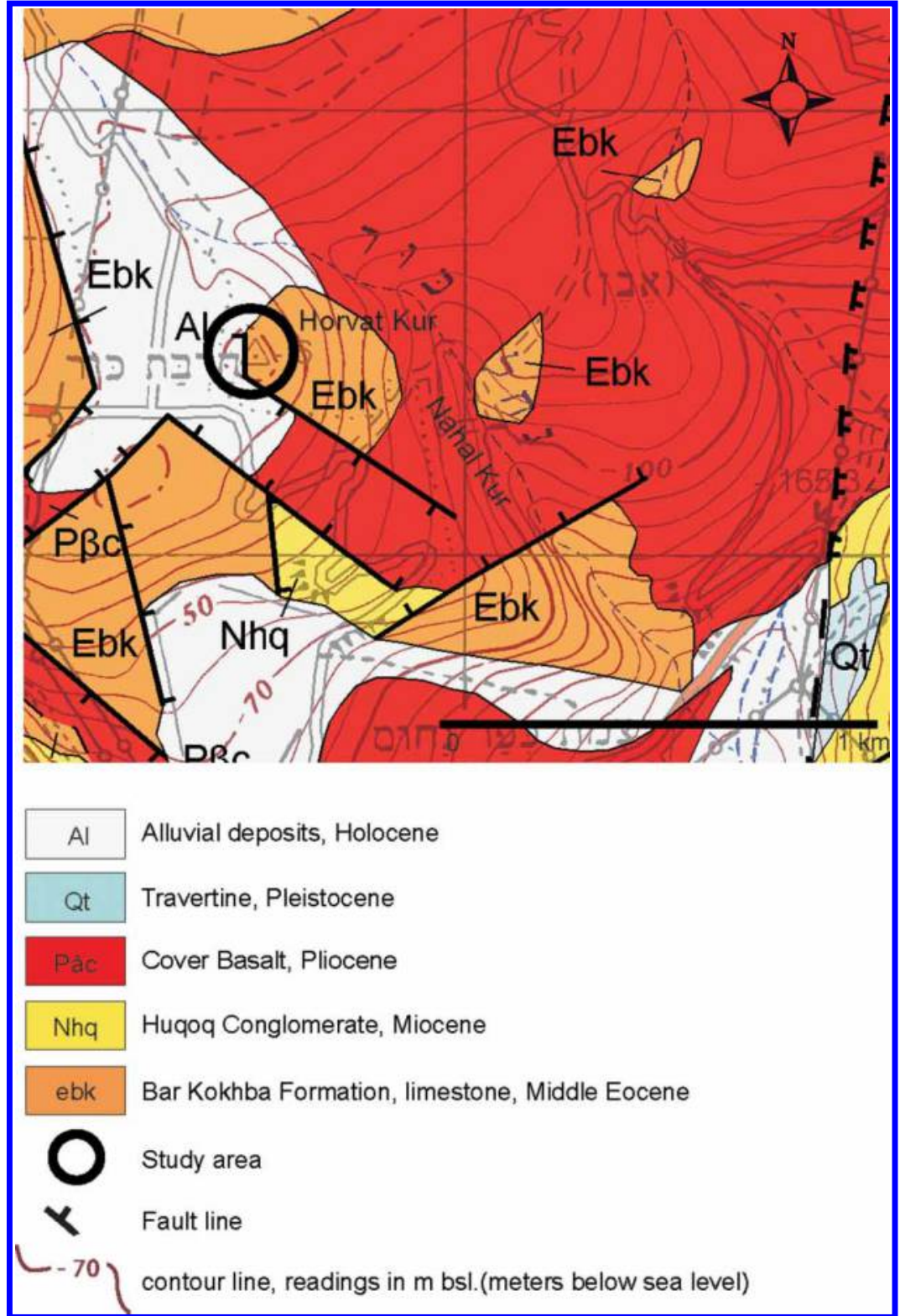

Figure 4 Geology of Horvat Kur (after Sneh 2008).

Ginnosar plain close to the lakeshore), ca. $2.9 \mathrm{~km}$ to the south of Horvat Kur - being within the same vegetation unit - features grasses like Triticum dicoccoides, Hordeum bulbosum, Bromus alopecurus, Leguminosae, e.g. Trifolium pilulare, as well as Brassicaceae, Scabiosa prolifera and a diversity of Astereaceae, e.g., Scolymus maculatus, Carthamus glauca and Echinops sp. (Gutman 1978, Gutman et al. 1999). Gutman (1978) describes the region of Karei Deshe as treeless with a few individuals of Quercus ithaburensis, Ceratonia siliqua, Pistacia atlantica, Ziziphus spina-christi and neophytic Eucalyptus. Zohary (1982) mentions for the same vegetation unit (Ziziphospinae-christi-Hyparrhenietum hirtae) among others Anchusa astrigosa, Convolvulus dorycnium, Echium angustifolium, Carlina involucrate and Gundelia tournefortii. Ziziphus lotus with herbaceous vegetation, e.g., Avena sterilis, Bromus palaestinus,
Hordeum ithaburense and other grasses, S. prolifera, Echium judaeum, C. dorycnium, Glypsophila arabica, Salvia horminium and numerous Asteraceae (e.g. Echinops viscosa, G. tournefortii, Carthamus glaucus, Anthemis pseudocotula) can be found on the eastern shore of the lake to the southwest of the site (Zohary 1982; Baruch 1986; Danin 1999). Acacia albida may grow in a few areas and points, together with thermophilous Ziziphus, to high winter temperatures (Danin 1995).

Quercus ithaburensis forests cover the slopes of the Galilee, e.g. north of Horvat Kur, and the Golan heights at an altitude between 0 and $500 \mathrm{~m}$ asl. Typical arboreal components are Styrax officinalis, P. atlantica, Pistacia palaestina, Quercus calliprinos, shrubs like Majorana syriaca and many herbaceous plants, e.g. grasses (Baruch 1986; Danin 1999). About $10 \mathrm{~km}$ west of the site open forests with 
Ceratonia siliqua, Pistacia lentiscus grow mostly on Terra Rossa soils. Northwest of Horvat Kur, in the Upper Galilee, Mediterranean maquis and forest dominated by the sclerophyllous evergreen Quercus calliprinos and deciduous Pistacia palaestina on hard limestone with Terra Rossa soil are widespread (Danin 1999). Woodlands with Qistacia calliprinos accompanied by Quercus boisseri, Crataegus monogyna and Prunus ursine and diverse herbaceous undergrowth on basalt are common in the northern Golan heights between 400 and $1200 \mathrm{~m}$ asl (Baruch 1986; Danin 1999). Synanthrophic vegetation with intensely cultivated areas can be found in the southern Golan and in the Huleh valley, where remnants of the original swamp vegetation with Cyperus papyrus, Phragmites australis, Arundo donax and Typha domingensis still prevail (Danin 1999).

\section{Materials and methods}

\section{Archaeological and palynological methods}

At the end of the 2011 campaign, remains of at least three pools were found attached to the northern synagogue wall (Loci 7129, 7295 and 7160; from east to west). When cleaning the northern balk of squares AC 28 and AD 28 in area A, the opening to a large bell-shaped cistern was found and finally documented and surveyed during the 2012 season (Fig. 5).

The cavity was three dimensionally surveyed by means of portable electronic instruments, such as a laser rangefinder, a digital clinometer and a prismatic compass. The data obtained, allowed generating a line plot with the aid of the cave surveying software Toporobot in order to visualise both, a vertical projection and horizontal projection of the cistern (see Fig. 8). The resulting plans were finally edited in a standard graphic computer application (Y. Shivtiel and B. Langford, 30.8.2012, pers. commun.).

Measurements of finds inside the cistern were taken relative to a tachymetrically established benchmark below the cistern's opening. This allowed three-dimensional referencing of artefacts and samples for pollen analysis inside the cistern using basic surveying tools (J. Ballard and D. Kessi, 13.7.2012, pers. commun.).

During examinations, three sediment samples were collected from the cistern for preliminary pollen analysis (see Fig. 8): two from sediments inside two cooking pots found on the surface of the accumulated sediment in the cistern (no. 20008 and no. 20009, Figs. 6 and 7) and a third sample (no. 19846) from a basket of sediment excavated next to cooking pot 2 (no. 20009)

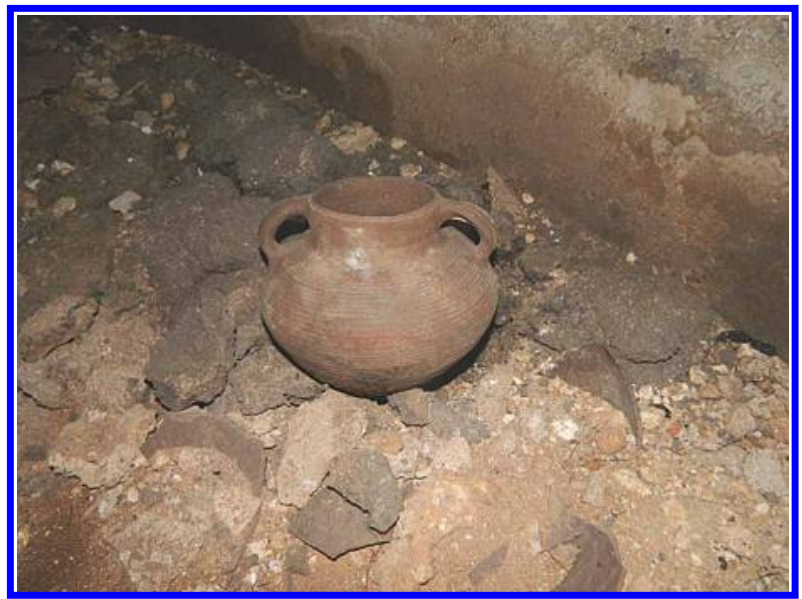

Figure 6 Complete Byzantine cooking pot 1 (registration no. 20008) on top of cistern sediment.

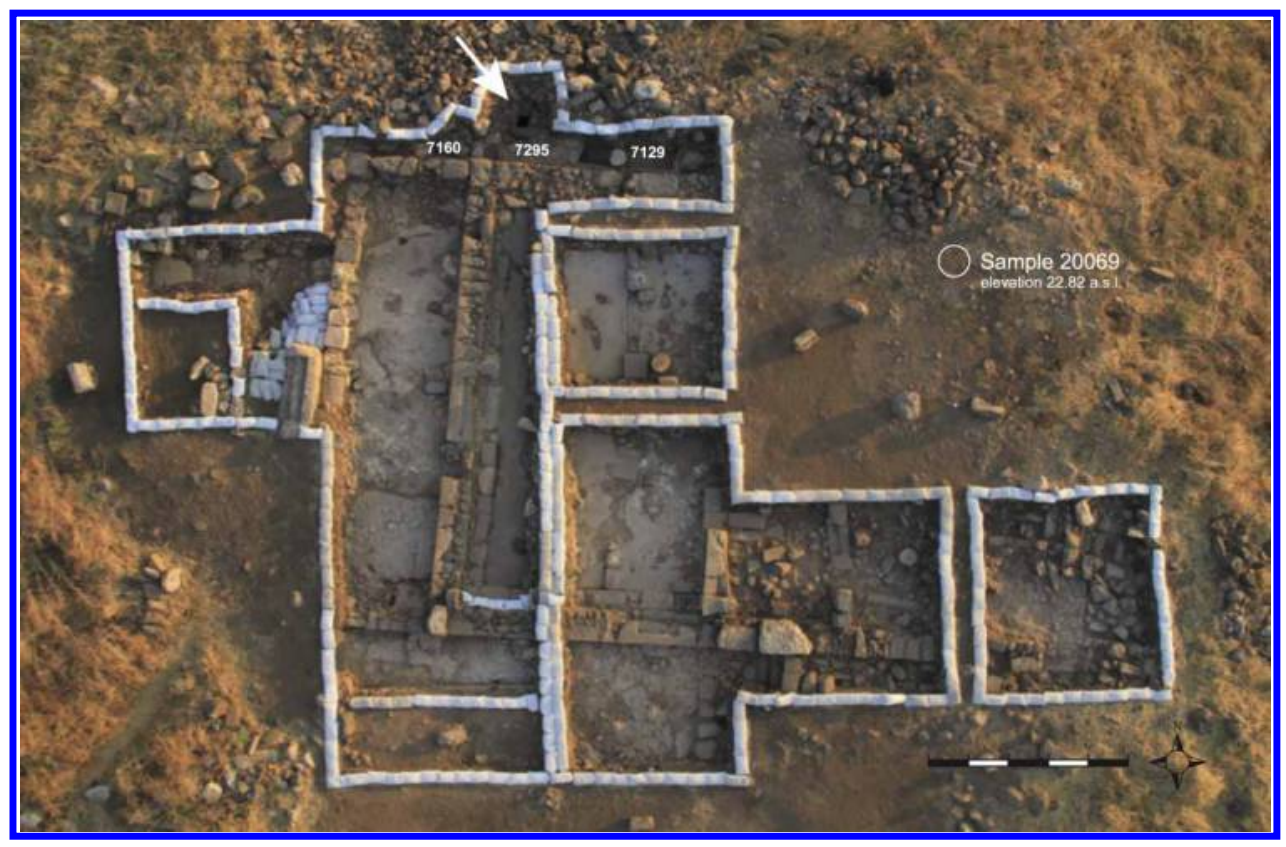

Figure 5 Arial view of the synagogue with opened cistern (arrow) and marked loci 7160, 7295 and 7129 just north of the synagogue northern wall at the end of the 2011 campaign; also note the indicated find spot of sample no. 20069 (๑) Skyview and Kinneret Regional Project). 


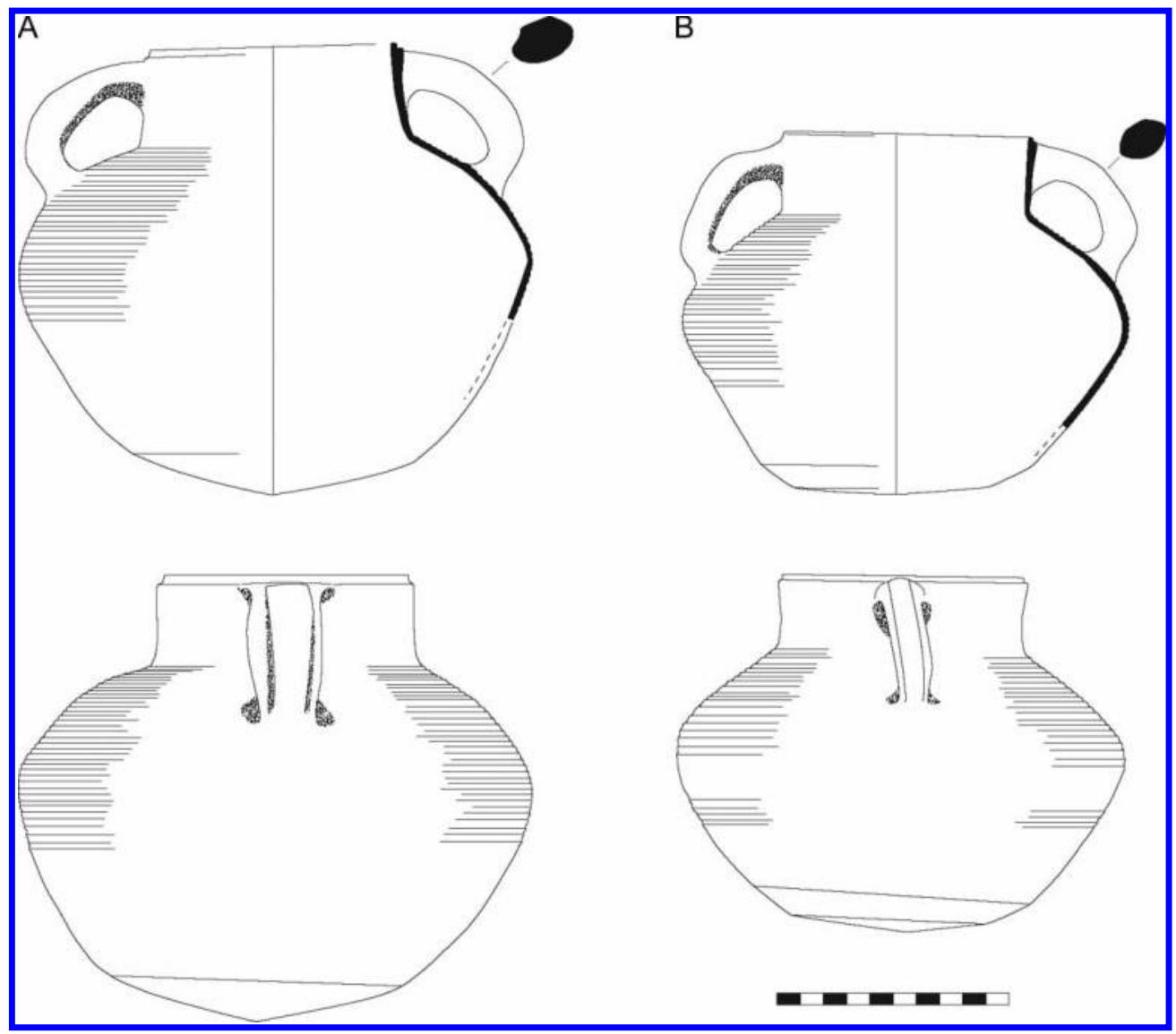

Figure 7 (a) Cooking pot 1 (registration no. 20008) and (b) Cooking pot 2 (registration no. 20009) (drawings by Christa Lennert, $\odot$ Kinneret Regional Project).

(for the individual positions see Fig. 8). For comparison with modern pollen flora a fourth sample was taken with a trowel from the modern surface close to the excavation site from an area of about $4 \mathrm{~m}^{2}$ (Fig. 5, no. 20069). Each sample was weighing between 7,5 and $25 \mathrm{~g}$.

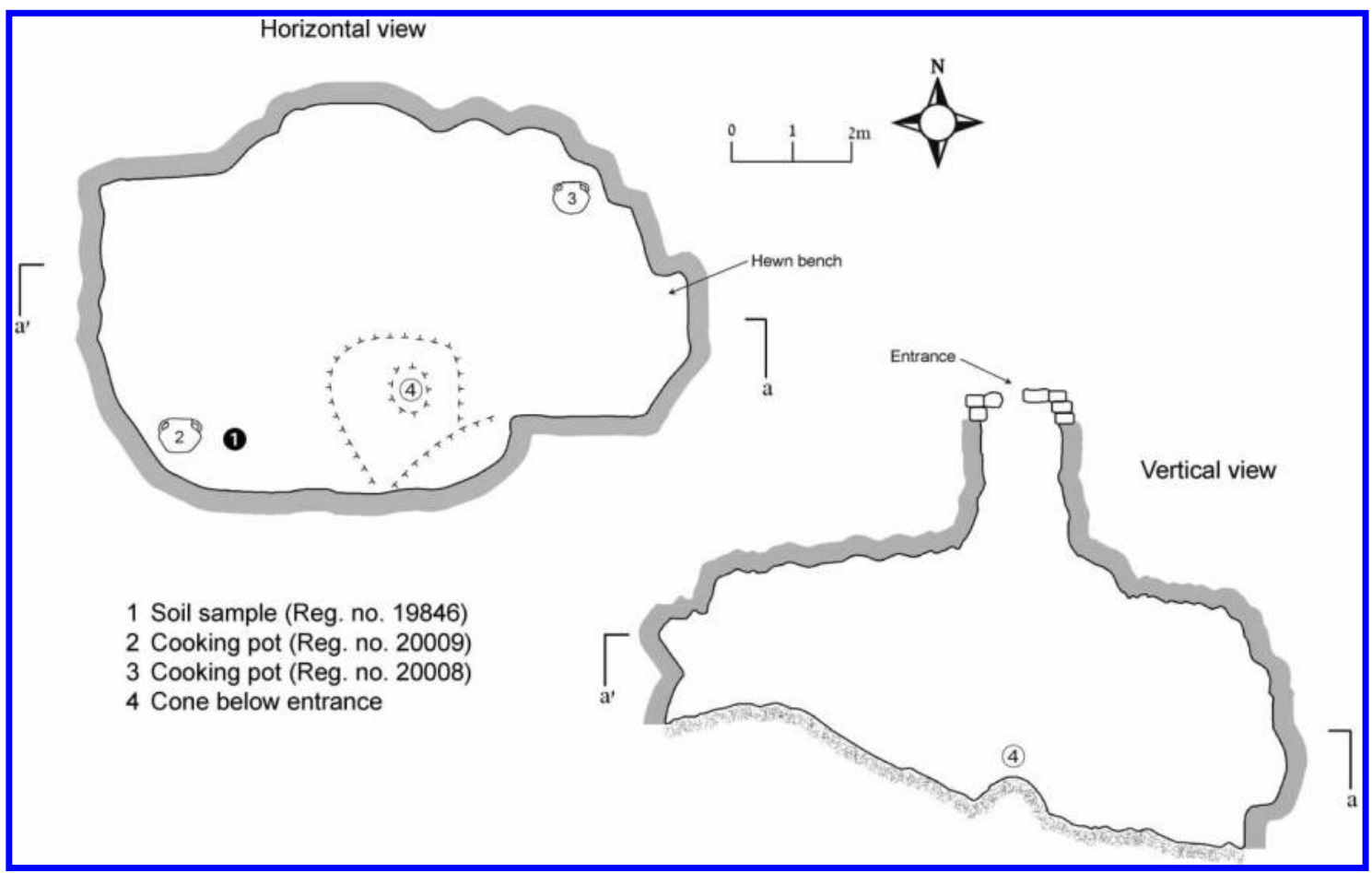

Figure 8 Sketch plan of cistern with find spots of pots, locations from which samples were taken (drawing by Boaz Langford and Yinon Shivti'el, () Kinneret Regional Project). 
The samples were split, and the part selected for pollen processing was weighted (20009: $9.9 \mathrm{~g}, 20008$ : $76 \mathrm{~g}, 19846: 109 \mathrm{~g}, 20069: 166 \mathrm{~g})$. We archived ca. $50 \%$ of each sample for possible later studies, e.g., the investigation of phytoliths. The sediments were processed according to palynological standard preparation techniques (Faegri and Iversen 1989; Wood et al. 1996). Before processing two Lycopodium clavatum spore tablets were added to each sample for the calculation of pollen concentrations (Stockmarr 1971). Palynomorphs were isolated from the sediment with $30 \% \mathrm{HCl}, \mathrm{KOH}, 48 \% \mathrm{HF}$ and acetolysis. Sodium polytungstate was used for heavy liquid separation. The residues were sieved over 10 and $250 \mu \mathrm{m}$ mesh screens and then mounted in permanent glycerinejelly slides. For pollen identification a pollen reference collection at Forschungsstelle für Paläobotanik at University of Münster, pollen atlases and references were used (Horowitz and Baum 1967; Reille 1990, 1992, 1995, 1998; Beug 2004). The nomenclature followed Beug (2004). However, several pollen-types only appearing in the Near East are named according to Baruch $(1990,1993)$. Ca. 500 terrestrial pollen grains were counted per sample. Berglund and Ralska-Jasiewiczowa (1986) emphasise that minimally 500 arboreal and non-arboreal pollen grains have to be counted in open landscapes in order to reach statistically significant results. The palynological results were plotted with the help of the pollen calculation application TILIA 1.7.16. Slides, residues and remaining sediments are stored at Forschungsstelle für Paläobotanik, Münster.

\section{Results}

\section{The cistern}

When parts of three large, roughly hewn oblong basalt capstones and below a carefully walled opening were gradually laid bare, the excavation area was extended to the north for about a meter. It soon became clear that the opening - measuring approx. $1.20 \mathrm{~m}$ in diameter - actually belonged to a cistern whose original entrance and cover stones had apparently been preserved in situ, thus sealing this water installation since the time of its original use.

A first examination of the cistern revealed a low oxygen level. After two days of fresh air circulation, a first exploration of the cistern was possible and its archaeological potential could be assessed.

The cistern opens through a narrow chimney of about $1.5 \mathrm{~m}$ and widens immediately afterwards into a broad, roundish cave extending well below the synagogue (Fig. 9). The cistern is approximately $6.5 \mathrm{~m}$ deep and measures $8.5 \mathrm{~m}$ on its east-west axis, and $7.1 \mathrm{~m}$ on its north-south axis. It appears to be a naturally formed cavity (in contrast to quarried cisterns that facilitated water harvesting and storing and

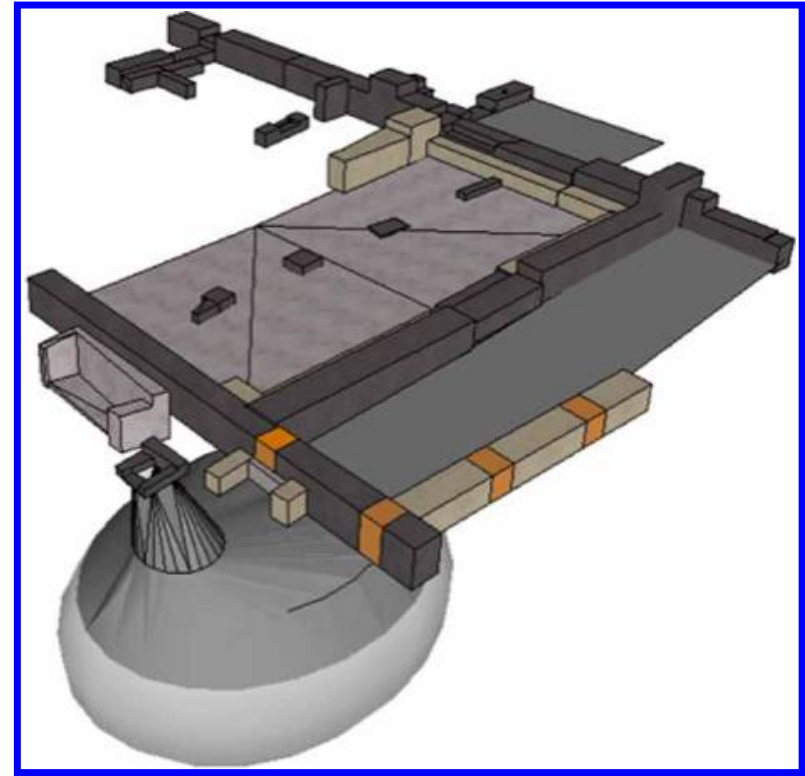

Figure 9 Axonometric graphic of cistern in relation to synagogue (graphics Damian Kessi, (c) Kinneret Regional Project).

produced building materials as a side product, see also Kloner 2001-2002, Ackermann 2008), but several man made niches or shelves are visible.

The bottom of the cistern is declining from west to east and consists of silty/clayey material including few stones and large quantities of pottery. The normally high sediment cone below the cistern's opening - typical for water installations that stood open for a long time and were exposed to material falling down - had apparently built-up only for about $1.15 \mathrm{~m}$. The high standing sediment in the western part of the cistern is possibly due to cracks in the ceiling and along the side walls that allowed sediment accumulation during the post-Byzantine era in this part of the cavity. The cistern was carefully plastered on the interior (Fig. 10). The plaster consisted of at least two layers and does not show any signs of repair. The first layer was white with grey grain, the second, lower, layer being of reddish colour.

During the first explorations, which did not include sub-surface excavations, two complete cooking pots were found directly on the surface of the sediment filling the cistern (no. 20008 and 20009; see Figs. 6 and 7).

\section{The pottery}

The two cooking pots are common, local Galilean household ware known during the Byzantine period (Fig. 6 and 7). They are of typical dark red-brown, micaceous ware and have a filling quantity of ca. 3.61 (no. 20008) and ca. 2.51 (no. 20009), respectively (measured according to Senior and Birnie's improved stacked-cylinder-method (1995: 324-330).

Despite slight differences in form, both vessels can on the basis of the exterior ridge below the lip - be 


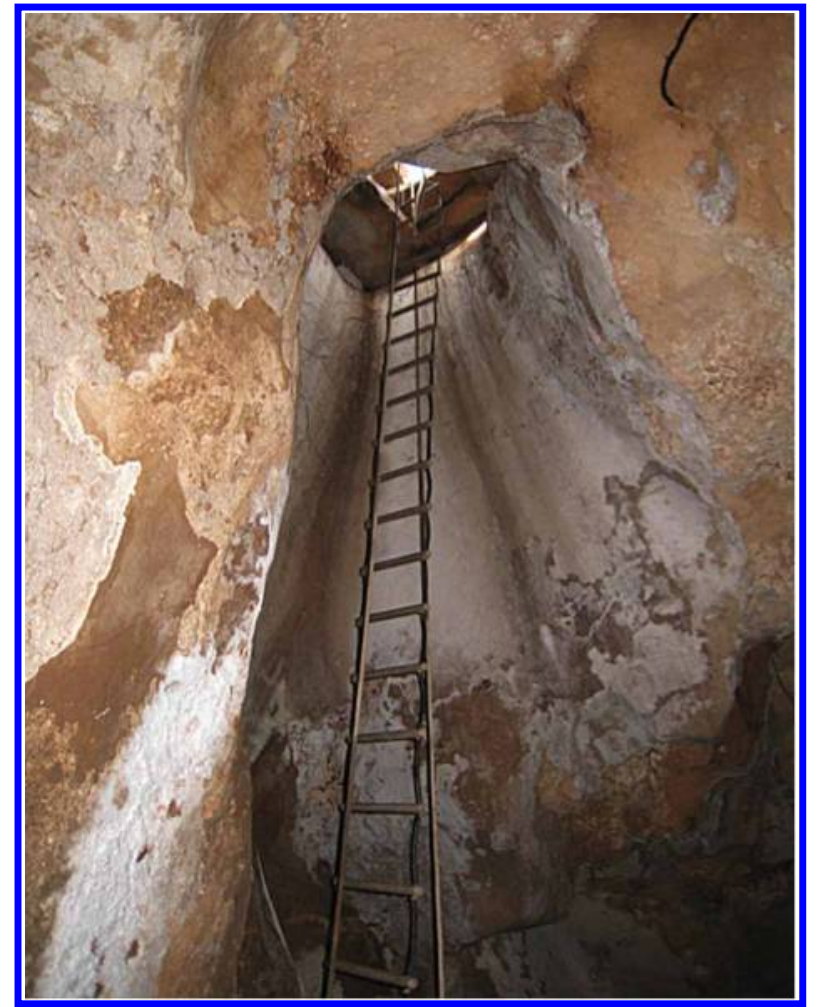

Figure 10 Entrance to cistern with chimney and widening cave. (๑ Kinneret Regional Project).

assigned to Kfar Hananya type 4E1 (Adan-Bayewitz 1993: 132-135), which dates to the 'earlier fourth to earlier fifth century' (Adan-Bayewitz 1993: 135; see also Loffreda 2008, 153: plate DG 173 nr. 33). Cooking pots are by no means unusual finds in cisterns, apparently because cooking pots could easily be lowered on a rope slung around the neck and through the handles, filled with water and be pulled up again, as e.g. the excavations at Meiron showed (Ritterspach 1974; Meyers et al. 1981; 94-105). Lacking any soot on the bottom as it is common on pots used for cooking, it is very likely that these two specimens were used for drawing water only. Taking together with observations in the layout of the cistern like plastered benches along cistern walls, the presence of cooking pots may also point to the possibility that the cistern at one point was used as storage facility (see Geoarchaeological and archaeological implications.). Both cooking pots were filled to about two-thirds with reddish-brown hard-packed sediment (see below).

\section{Sedimentological description and palynological results}

The properties of the sediments in the cooking pots, a sediment sample from immediately next to one of the pots from the cistern floor and a modern surface sample are given in Table 1. The soil texture was estimated by finger testing and Munsell Soil Color Charts (1994) were used to determine sediment colors.

Palynological analysis of all sediment samples revealed a large amount of pollen (Fig. 11). Pollen preservation is in general good, with no obvious difference between modern pollen from the surface sample and the palynomorphs from the archaeological context. The percentage of tree pollen, mainly Pinus and $O l e a$, is relatively low whereas the diverse herbaceous pollen flora is characterised by Asteraceae, a.o. Scorzonera pollen-types, diverse Centaurea pollentypes and Matricaria-type, Geraniaceae, e.g. Geranium and Erodium, Poaceae, Apiaceae, Brassicaceae, Caryophyllaceae, Theligonum cynocrambe and others. Scabiosa and Malvaceae are common and especially abundant in one of the cooking pot samples. Only few isolated pollen of Cyperaceae were found. Fragments of charred particles were counted in two categories $(>50$ and $>100 \mu \mathrm{m}$ ) and are strongly fluctuating from one sample to the other. Sixty-seven pollen types were identified, Fungi and Zygnemataceae appeared in low numbers and spores of cryptogams were not found.

\section{Discussion}

\section{Palaeoecological implications}

The modern surface sample 20069 reflects an open landscape with only very few trees, e.g. Olea, Pistacia and Pinus, although especially Olea and Pinus produce pollen in large quantities which are transported by wind via large distances (Fig. 11). Spores of cryptogams and pollen of aquatics or swamp plants, e.g. Cyperaceae, are lacking. Otherwise the herbaceous flora seems, according to the modern pollen spectrum, to be comparably diverse, with a dominance of Matricaria-type pollen (46\%), numerous other Asteraceae including Centaurea scabiosa and Carduustype, and a strong appearance of cf. Scorzonera hispanica pollen (ca. 20\%). Achillea species do not grow at the northern shore of the lake, but in Upper Galilee and the Golan heights (Danin 2004). Anthemis is much more prominent around the Lake, numerous species are widespread on maquis, roadsides, fallow and abandoned fields. Pollen of the genera Achillea and Anthemis are palynologically undistinguishable and are here described as Matricaria-type (Beug 2004). Scorzonera subintegra is common in Upper Galilee, Scorzonera papposa abundant allover Israel, but occurs most frequently at the Lake Tiberias (Feinbrun-Dothan and Danin 1991; Danin 2004). Poaceae pollen reach $>5 \%$, and Brassicaceae are quite common. In general, the pollen spectra might easily point to Mediterranean savannoid open land vegetation (see above, compare Danin, personal communication 2011) with an abundance of Poaceae and Asteraceae 
Table 1 Soil properties of cistern and surface sediments

\begin{tabular}{|c|c|c|c|c|}
\hline $\begin{array}{l}\text { Sample } \\
\text { no. }\end{array}$ & Sedimentological description & $\mathrm{HCl}$ reaction & $\begin{array}{l}\text { Colour (Munsell Soil } \\
\text { Color Charts 1994) }\end{array}$ & Remarks \\
\hline 20069 & $\begin{array}{l}\text { Few pebbles, clayey, silty sand, } \\
\text { humic }\end{array}$ & $\begin{array}{l}\text { Very strong, carbonate } \\
\text { concretions }(5 \%)\end{array}$ & $5 Y R / 5 / 1$ & $\begin{array}{l}\text { Surface sample, loose, fine } \\
\text { granular structure }\end{array}$ \\
\hline 20009 & Silty clay, few sand grains & $\begin{array}{l}\text { Strong, carbonate } \\
\text { concretions }(2 \%)\end{array}$ & 10R/6/1, mottled & $\begin{array}{l}\text { Cooking pot } 2 \text {, sediment } \\
\text { cemented, granular } \\
\text { structure }\end{array}$ \\
\hline 20008 & Silty clay, few sand grains & $\begin{array}{l}\text { Strong, carbonate } \\
\text { concretions }(2 \%)\end{array}$ & 10R/7/1, mottled & $\begin{array}{l}\text { Cooking pot } 1 \text {, sediment } \\
\text { cemented, granular } \\
\text { structure }\end{array}$ \\
\hline 19846 & $\begin{array}{l}\text { Few pebbles/stone fragments, } \\
\text { humic, sandy, silty clay }\end{array}$ & $\begin{array}{l}\text { Very strong, carbonate } \\
\text { concretions }(5 \%)\end{array}$ & $5 Y R / 4 / 2$ & $\begin{array}{l}\text { Next to 20009, loose, granular } \\
\text { structure }\end{array}$ \\
\hline
\end{tabular}

although the lack of Ziziphus pollen is conspicuous. The genus Ziziphus is in general insect pollinated (TelZur and Schneider 2009), thus pollen may be underrepresented in pollen spectra. A study on annual variations of pollen in the Coastal Plain of Israel has shown a weak representation of Ziziphus-pollen restricted to March (Keynan et al. 1991). Some pollen types, e.g. Scabiosa, Carthamus-type, Matricaria-type and Echinops, are typical for Ziziphus lotus communities as found to the southwest of Horvat Kur (Fig. 3, cf. Zohary 1962; 1982), but such typical Mediterranean elements might also occur in the Mediterranean savannoid vegetation close to the study area. Only observed neophyte is a single Carya pollen. Pollen of Carya, a North American nut tree cultivated in modern Israel, is known from recent samples from the Birkat Ram core (Neumann et al. 2007b).

The pollen spectra of samples 20008 and 20009 from the Early Byzantine pots show similar spectra but numeric differences compared to the surface sample. Pollen concentration is reasonable. Pollen of swamp plants and spores are lacking, pointing to rather dry conditions and the absence of wetlands in the vicinity. In general, grasses are more common in both samples $(>15 \%)$, Matricaria-type is less prominent and pollen of cf. Scorzonera hispanica is especially characteristic ( $>50 \%$ in 20008 , ca. $40 \%$ in 20009). Scorzonera laciniata-type (after Beug 2004) appears in low numbers, other Asteraceae, e.g. diverse Centaurea pollen types also occur. The question, if pollen of Scorzonera, belonging to Cichorioideae, might be overrepresented, is difficult to solve (see Objectives). In the light of generally good pollen preservation we assume that the high percentages of Scorzonera pollen are indeed reflecting the vegetation during the Byzantine period. Additionally, both samples have a high pollen concentration, similar or only slightly lower than the surface sample. Percentages of Varia are between 5 and $11 \%$ which signals moderate pollen deterioration. Whereas, sample 20008 features Atriplex, Liliaceae and a higher number of Varia (which points to a slightly weaker preservation of palynomorphs), sample 20009 is characterised by the strong appearance of pollen of Scabiosa argentea-type, Scabiosa graminifolia-type and Malva pollen. Theligonum cynocrambe, especially widespread at Lake Kinneret nowadays (Danin 2004), is more common. These differences can be explained by seasonal fluctuations of pollen in the air (Keynan et al. 1991): Malvaceae pollen can only be observed in the coastal plain from March to April, Scabiosa prolifera, abundant at Lake Kinneret, flowers between March and May, Scabiosa palaestina in May (Feinbrun and Danin 1991, Danin 2004). The pollen content of sample 19846, taken next to pot 2 (20009), does not differ much from the sediments found within the cooking pots. The pollen concentration of sample 19846 is between the concentrations of samples 20008 and 20009. Pollen percentages of Poaceae, cf. Scorzonera hispanica, and many Asteraceae are comparable. Only conspicuous differences in comparison to 20009 are lower percentages of Theligonum, Scabiosa and Malva pollen, whereas in general the pollen diversity seems to be comparably higher. Pollen grains of Mercurialis, Pimpinella and Biscutella are missing in the sediments of the cooking pots $(20008,20009)$. The values of charred particles are low and comparable to those of 20008 . Generally, all fossil samples show comparable pollen spectra and pollen concentrations.

A similar picture is given in both the samples of the early Byzantine period and the surface sample with the most significant difference being a single Carya pollen and much higher Matricaria-type pollen in the modern surface sample. Matricaria-type pollen might point to an even stronger human impact/maquis in the modern landscape. It should be mentioned that pollen of the Matricaria-type are robust to corrosion, having a thick, spiny exine. Sample 20009 from within one of the pots features high values of Malva and Scabiosa pollen. Pollen of Theligonum cynocrambe only appears in the Byzantine samples. T. cynocrambe is especially abundant in the Kinrot valley (Danin 2004). The overall similarity of both fossil and modern pollen spectra as well as comparable and overall high pollen concentrations is in itself a 


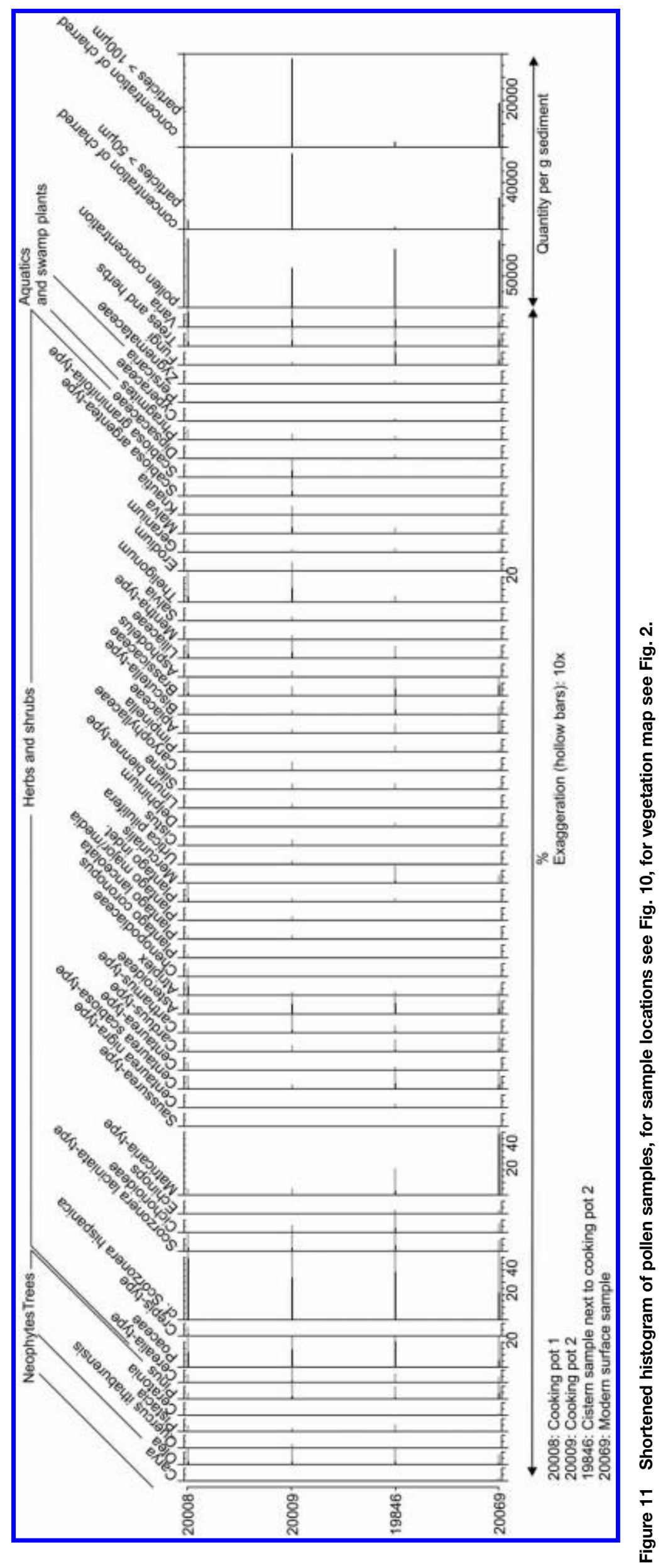


remarkable observation. The number of crumpled and unrecognisable pollen (varia, Fig. 11) is only slightly lower in the modern sample whereas the pollen concentration is even higher in fossil sample 20008, on the other hand the pollen concentration of sample 19846 is only slightly lower (median of all samples: $100,262.5$ pollen grains/g). However, the stronger appearance of Poaceae and Sorzonera pollen in the samples from the cistern pots might be either explained by differential pollen preservation (see section 1.2) or seasonal differences but the possibility of a slightly different vegetation with more grasses and Scorzonera during the early Byzantine period cannot be excluded. The sediments of both modern and Byzantine samples are probably alkaline, since carbonate concretions were found. Enrichment in $\mathrm{CaCo}_{3}$ is a typical phenomenon of soils in semi-arid regions (Schachtschabel et al. 1992) and high $\mathrm{pH}$ may lead to pollen deterioration (Dimbleby 1957, Bryant et al. 1994). However, the degree of pollen degradation in the Byzantine samples does not seem to be overwhelming. Pollen of Cerealia, not differentiated further in the present study, play a weak role in all three samples. Quercus ithaburensis, Q. calliprinos, Pistacia and Ceratonia pollen are rather rare. In any case the picture of a largely treeless, herbaceous vegetation with a dominance of Asteraceae and the absence of agricultural plants with possible exception of pollen of cultivated Olea and Linum is intriguing. The semi-arid character of the landscape is underlined by low values of swamp plants whereas spores of cryptogams were not found. Fungal growth is moderate. This preliminary result will remain an important point of future discussion when more samples become available for testing, especially in the light of other pollen records from the region, e.g., Lake Tiberias, Huleh and Birkat Ram which point to a strong presence of olive, grape, carob, cereals and accompanying weeds (e.g., Baruch 1986, 1990; Neumann et al. 2007b). This contrast might be explained by a very local representation of the vegetation in our pollen spectra, the overrepresentation of asteraceous shrubs, which are strong pollen producers, and the possible absence of cultivars in the immediate surroundings of the site. The pollen spectra can be tentatively interpreted as a sign for a climate and vegetation which is rather similar to the one today although more samples are necessary to confirm this interpretation. The strong presence of pollen of grazing resistant plants - especially many Asteraceae, e.g., Carduus-type, probably indicates animal husbandry in the area. Contamination does not seem to play a major role. Obvious, but rare contaminants in the slides have still their cellular content (and therefore have not undergone acetolysis, meaning that those contaminants entered the slide probably during mounting with glycerine jelly) and belong to the European species Carpinus betulus, Betula sp., Fagus sylvatica which are either absent or rare in pollen spectra from the region. The good pollen preservation, also reflected in the rather low percentages of crumpled pollen (Varia: minimally $2.6 \%$, maximally $10.6 \%$, median: $4.5 \%$ ), might be explained by dysoxic conditions at the floor of the sealed cistern which were already observed by the excavators (see above). Charred particle fragments, most likely derived from bush fires, are rather rare with the peculiar exception of sample no. 20009.

\section{Geoarchaeological and archaeological implications}

As only limited excavations around the opening were possible in 2011, not much can at present be said about the functional context of the cistern. It appears that both the cistern and the three adjoining pools (Loci 7129, 7295 and 7160) are parts of installations to collect and store rain water from the large roof of the synagogue. However, the possibility that water was collected from nearby aquifers cannot be excluded (see below). Collecting runoff from roofs is a well-established technique at least since the Early Bronze Age, the runoff coefficient might have been up to $>50 \%$ (Yair and Garti 2003). Since Horvat Kur has no direct access to spring water, we can assume that cisterns are among the first structures to be built by anybody who wanted to settle on the hill. Although no absolute date can be given for the construction of the cistern at the moment, one can assume that the cistern discussed here belongs to the oldest structures at the site - just like dozens of others, which are often collapsed. The cistern was dug into karstic limestone. The spot was well chosen, the limestone kept the water cool and the rock was easily workable.

The alluvial plain close to Horvat Kur, which is still cultivated today due to its deep and fertile soil, was also used for agriculture. Cultivation was facilitated by numerous agricultural and water management features such as water channels and cisterns, which were mapped locally in 2008 (M. van der Enden, pers. commun.). Additionally, the fertile soils on basalt to the east of Horvat Kur may also have been used for agricultural purposes. Pollen of cultivars, e.g. Olea, are rare in all sediment samples. In general the basaltic hill lands are suitable for Mediterranean dry farming, which includes the cultivation of olives (Olea europaea), grapes (Vitis vinifera), flax (Linum) and cereals. The few springs within the basalt hill lands are often located along the wadis at the base of geological faults (Leibner 2009). The location on a crag and the relatively steep slopes towards Nahal Kur probably offered natural protection. 
(a) The following hypothesis is suggested to explain the location of the cistern: Water is often transported along faults in form of aquifers. Close to the site two faults can be observed, which run North-South and Northwest-Southeast, respectively. Both faults separate Eocene limestone from basalt. Water, originating from springs along the fault lines, might have been collected and stored in the cistern together with runoff water which was directed via a small channel into the cistern. In a similar way the location of other cisterns in Horvat Kur might be explained by the peculiar geology, especially the tectonics, of the area. However, a geological/geoarchaeological survey is needed to prove this hypothesis. As mentioned above, water installations close by point to the fact that runoff water from the roof of the synagogue and plastered areas close by was collected in the cistern.

(b) Returning to the question of chronology: The existence of two different kinds of plaster - as mentioned above (Fig. 10) - may indicate several phases of use. The grey plaster is known from the Hellenistic and early Roman periods, while the red plaster can be attributed to the Byzantine period (Porath 1989). The latter accords well with the two cooking pots, picked randomly from the large amount of deposited pottery and dating to the end of the 4 th / beginning of the 5th century AD (see above and Figs. 6 and 7). Their date, together with other finds from the same debris still to be retrieved and analyzed, can not only help to establish the date of the last use of the cistern as water storage facility, it could also help understanding the character of its subsequent use.

(c) The fact, namely, that two complete cooking pots together with many more fragments of household vessels were found directly on the surface of the silt layer (nos. 20008 and 20009; see Figs. 6 and 7) raises the question about different phases of use in the cistern. It is possible that the two pots were fragmented during a period of low water levels in the cistern but another option is the loss of the vessels during a period of high water level. As no subsurface excavations have been carried out by the time the cistern was explored for the first time, all conclusions on that matter must remain provisional. However, the phenomenon as such warrants an explanation. Since cisterns can be expected to be frequently purged during their use, the accumulation of silt and pottery on the bottom can only have occurred when its use as water storage facility came to an end and no effort was made anymore to keep it clean. Meticulous excavation of the sediment will help understand its character (did the debris include household waste, was it washed in?). In any case, once the cistern went out of use, the ancient inhabitants sealed it with the long basalt slabs that were encountered by the present expedition in 2011.
The cistern may have been used as habitational or storage space for household goods after its use as water reservoir had ceased and before it was finally sealed. It may be assumed, that the cistern - as in other sites - at one point became a hideout complex (Shivti'el 2009), but the Late Roman/Early Byzantine date of the cooking pots indicates that this change, if at all, occurred at a considerably later date than the 'classical' hideout period during the First or Second Revolt. Only a time- and cost-intensive excavation of the complete cistern will reveal if it was used as a hideout at some time in the past.

Finally, the reasons for taking such a carefully hewn cistern out of use remains unclear at this stage of research and must be addressed in the future.

\section{Conclusions and future prospects}

Our preliminary pollen results show a great potential for further palynological study in the cistern. Supported by archaeobotanical findings, they underline the importance of local studies. Although only very few samples were analyzed and the population is too small for statistical analysis, they not only feature good pollen preservation, moderate percentages of Varia and high pollen concentration, but also similar floral characteristics to a modern surface sample. According to Bryant et al. (1994: Figs. 4.6. and 4.7.) a statistical correlation exists between low pollen concentrations and high percentages of indeterminate pollen (Varia), pointing to progressive deterioration of palynomorphs. Consequently, pollen deterioration in our case seems moderate. All three samples collected in the cistern point to predominantly herbaceous, grassy vegetation with numerous Asteraceae, which seems to be typical for a savannoid Mediterranean vegetation still characteristic of the local landscape in the vicinity of Horvat Kur (compare modern surface sample for reference). Additional cultivars are nearly absent from both the modern and Byzantine sample; therefore, showing a lack of cultivation close to the site although pastoralism on open grassland seems likely. A local study by Gutman et al. (1999) has shown that some Asteraceae, e.g. S. maculatus, increase in abundance under conditions of heavy grazing. Pollen of Asteraceae is abundant in all pollen spectra, although identification to species level within the family is often palynologically difficult.

The cistern itself probably was hewn - with undoubtedly numerous others - when the hill was permanently settled, perhaps, as the greyish plaster suggests, during the last decades of the 1st ca. BC or the first decades of the 1st ca. AD when the Galilee as a whole witnessed a settlement boom (Leibner 2009). As hewing cisterns is a tremendous effort and 
requires careful observation of runoff areas and planning of channels/water distribution and a planned organisation of space in the future village, the construction of the cistern would have strongly influenced the infrastructure and character of the nascent settlement. More research will also have to be carried out on this topic. In any case, it seems that the cistern remained in use as water storage facility until the Late Roman/Early Byzantine period (date of cooking pots) when it might have been turned into secondary household space and eventually abandoned and sealed, perhaps some time towards the end of the Byzantine period.

The cistern, in a way, reflects the course of habitation on Horvat Kur, and provides some valuable indications about the rural and common type of habitation. Palynological research has helped us to better understand the character of the landscape and how local inhabitants have adjusted to it but further research is needed. The open landscape above all seems to have invited pastoralism and animal husbandry, most likely sheep, whose wool was mostly used for textile production and meat be sold off for consumption. Further research in the habitational areas of Horvat Kur might reveal agricultural installations, e.g., granaries, which might give a better idea about the economical base of the village.

In 2012, more samples were obtained from a planned section which was dug from the surface of the fill down to the rock bottom of the cistern. The description of the profile and the pottery found within the sediment layers as well as possible palynological results will be described elsewhere. Radiocarbon dating of the section is planned. Samples taken in 2011 from the plaster of the synagogue and soils from various archaeological strata on the site are being analysed and will provide further insights into the palaeoenvironment of the site. The functional and chronological relationship between cistern and synagogue requires more study. Additionally, further field work is necessary to understand the sophisticated water installations at Horvat Kur and its connections to the regional geology, e.g., fault lines. The aim is to reconstruct the palaeo-landscape in the vicinity of the northern shore of the Sea of Galilee in order to understand settlement patterns and infrastructure especially during the Hellenistic-Byzantine periods.

\section{Acknowledgements}

We thank the Israel Antiquities Authority for granting license G42/2011 to Kinneret Regional Project (KRP). Our colleagues Rick Bonnie, Raimo Hakola, Damian Kessi, Tine Rassalle, James Ballard, Byron McCane and students from Finland, Switzerland, the Netherlands, Romania, USA, Germany, Belgium and Israel deserve our thanks for their hard and diligent work during the excavation. Many thanks go to Mordechai Aviam for fruitful discussions and to Anne Niehus for processing the samples. Boaz Langford assisted in surveying the cistern. The Deutsche Verein zur Erforschung Palästinas funded co-author Frank Neumann's participation in the 2011 and 2012 excavation campaigns. Thanks to Dafna Langgut, Eugene David Ungar, Avinoam Danin, Stefanie Jacomet, Lucia Wick, Hans Kerp, Christoph Hartkopf-Fröder, Ruth DrescherSchneider, Andreas Heiss and Oren Ackermann for fruitful discussions and sending helpful literature. Amos Frumkin and Dov Frimerman helped with sending geological maps of the region, Patricia Kearney checked the English. Two anonymous referees helped to improve the manuscript.

\section{References}

Ackermann, O. 2008. Reading the field: geoarchaeological codes in the Israeli landscape. Journal of Earth Sciences 56, 87-106.

Adan-Bayewitz, D. 1993. Common Pottery in Roman Galilee. A Study in Local Trade. Ramat-Gan: Bar-Ilan University.

Baruch, U. 1986. The Late Holocene Vegetational History of Lake Kinneret (Sea of Galilee), Israel. Paléorient 12, 37-48.

Baruch, U. 1990. Palynological evidence of human impact on the vegetation as recorded in late Holocene Lake Sediments in Israel, pp. 283-93 in Bottema, S., Entjes-Nieborg, G. and Van Zeist, W. (eds.), Man's Role in the Shaping of the Eastern Mediterranean Landscape. Rotterdam: Balkema.

Baruch, U. 1993. The Palynology of Late Quaternary Sediments of the Dead Sea. Unpublished PhD. dissertation, Hebrew University of Jerusalem, Jerusalem (Hebrew with English summary).

Baruch, U. 1994. The late quaternary pollen record of the Near East, pp. 103-20 in Bar-Yosef, O. and Kra, R. (eds.), Late Quaternary Chronology and Palaeoclimates of the Eastern Mediterranean. Tucson: Radiocarbon.

Baruch, U. and Bottema, S. 1999. A new pollen diagram from Lake Hula: vegetational, climatic and anthropogenic implications, pp. 75-86 in Kawanabe, H., Coulter, G. W. and Roosevelt, A. C. (eds.), Ancient Lakes: Their Cultural and Biological Diversity. Ghent: Kenobi Productions.

Berglund, B. E. and Ralska-Jasiewiczowa, M. 1986. Pollen analysis and pollen diagrams, pp. 455-84 in Berglund, B. E. (ed.) Handbook of Holocene palaeoecology and palaeohydrology. Chichester: John Wiley \& Sons.

Beug, H. J. 2004. Leitfaden der Pollenbestimmung für Mitteleuropa und angrenzende Gebiete. München: Verlag Dr Friedrich Pfeil.

Bottema, S. 1975. The Interpretation of Pollen Spectra from Prehistoric Settlements (With Special Attention to Cichorioideae). Palaeohistoria 17, 17-35.

Bryant, V. M. and Holloway, R. G. 1996. Chapter 23A. Archaeological palynology, pp. 913-7 in Jansonius, J. and McGregor, D. C. (eds.), Palynology: Principles and Applications. Salt Lake City: American Association of Stratigraphic Playnologists Foundation.

Bryant, V. M., Holloway, R. G., Jones, J. G. and Carlson, D. L. 1994. Pollen preservation in alkaline soils of the American Southwest. pp. 47-58 in Traverse, A. (ed.), Sedimentation of organic particles. Cambridge: Cambridge University Press.

Cerda, A. 1998. Relationships between climate and soil hydrological and erosional characteristics along climatic gradients in Mediterranean limestone areas. Geomorphology $\mathbf{2 5}$, $123-34$.

Cordova, C. 2007. Millenial Landscape Change in Jordan. Geoarchaeology and Cultural Ecology. Tucson: The University of Arizona Press.

Danin, A. 1995. Man and the natural environment, pp. 24-39 in Levy, T. E. (ed.), The Archaeology of Society in the Holy Land. London: Leicester University Press.

Danin, A. 1999. Desert rocks as plant refugia in the Near East. The Botanical Review 65, 93-170. 
Danin, A. 2004. Distribution Atlas of Plants in the Flora Palaestina Area. Jerusalem: The Israel Academy of Sciences and Humanities.

Davidson, D. A., Carter, S., Boag, B., Long, D., Tipping, R. and Tyler, A. 1999. Analysis of pollen in soils: processes of incorporation and redistribution of pollen in five soil profile types. Soil Biology and Biochemistry 31, 643-53.

Dimbleby, G. W. 1957. Pollen analysis of terrestrial soils. New Phytologist 56, 12-28.

Dimbleby, G. W. 1961. Soil pollen analysis. Journal of Soil Science 12, $1-11$.

Dincauze, D. F. 2004. Environmental Archaeology: Principles and Practice. Cambridge: Cambridge University Press.

Faegri, K. and Iversen, J. 1989. Textbook of Pollen Analysis Chichester: John Wiley \& Sons.

Feinbrun-Dothan, D. N. and Danin, A. 1991. Analytical Flora of Eretz Israel. Jerusalem: CANA Publishing House Ltd.

Fish, S. K. 1989 Appendix B: the Beidha pollen record, pp. 91-6 in Byrd, B. F. (ed.), The Natufian encampment at Beidha: Late Pleistocene adaptation in the Southern Levant. Jutland Archaeological Society Publications 23, Aarhus, Denmark: Aarhus University Press.

Galili, E. and Weinstein-Evron, M. 1985. Prehistory and Paleoenviroments of Submerged Sites along the Carmel Coast of Israel. Paléorient 11, 37-52.

Gavin, D. G. and Brubaker, L. B. 1999. A 6000-year soil pollen record of sub-alpine meadow vegetation in the Olympic Mountains, Washington, U.S.A. Journal of Ecology 87, 106-22.

Golodets, C., Kigel, J. and Sternberg, M. 2011. Plant diversity partitioning in grazed Mediterranean grassland at multiple spatial and temporal scales. Journal of Applied Ecology 48(5), 1260-8.

Gutman, M. 1978. Primary production of transitional Mediterranean steppe. Proceedings of the First International Rangeland Congress: 225-8.

Gutman, M., Perevolotsky, A., Ungar, E. D., Sternberg, M. and Kigel, J. 1999. Mediterranean herbaceous vegetation response to high animal density and grazing deferment: implications for management and conservation, pp. 161-4 in Etienne, M. (ed.), Dynamics and Sustainability of Mediterranean Pastoral Systems = Dynamique et durabilité des systèmes pastoraux méditerranéens. Zaragoza: CIHEAM-IAMZ.

Havinga, A. J. 1984. A 20-year experimental investigation into the differential corrosion susceptibility of pollen and spores in various soil types. Pollen et Spores 26, 541-58.

Heim, C., Nowaczyk, N. R., Negendank, J. F. W., Leroy, S. A. G. and Ben-Avraham, Z. 1997. Near East desertification: evidence from the Dead Sea. Naturwissenschaften 1984, 398-401.

Hevly, R. H. 1981. Pollen production, transport and preservation: potentials and limitations in archaeological palynology. Journal of Ethnobiology 1, 1, 39-54

Horowitz, A. 1988-1989. Pollen Analysis from Tel Tsaf. Tel Aviv 15-16, 55

Horowitz, A. and Baum, B. 1967. The arboreal pollen flora of Israel. Pollen et Spores 9, 1, 71-93.

Hunt, C. O., El-Rishi, H. A., Gilbertson, D. D., Grattan, J., McLaren, S., Pyatt, F. B., Rushworth, G. and Barker, G. W. 2004. Early-Holocene environments in the Wadi Faynan, Jordan. Holocene 14, 921-30.

Hunt, C. O., Gilbertson, D. D. and El-Rishi, H. H. 2007. An 8000 year history of landscape, climate, and copper exploitation in the Middle East: the Wadi Faynan and the Wadi Dana National Reserve in southern Jordan. Journal of Archaeological Science 34, 1306-38.

Hussey, T. 1991. Pollen Analysis of the Sepphoris Archaeological Site, BeitNatofa Valley, Lower Galilee, Israel,' Senior Schola Papers 122, Colby College.

Jacomet, S. and Kreuz, A. 1999. Archäobotanik-Aufgaben, Methoden und ergebnisse vegetations- und agrargeschichtlicher Forschung. Stuttgart: Verlag Eugen Ulmer.

Kadosh, D., Sivan, D., Kutiel, H. and Weinstein-Evron, M. 2004 A Late Quaternary paleoenvironmental sequence from Dor, Carmel Coastal Plain, Israel. Palynology 28, 142-7.

Keynan, N., Waisel, Y., Shomer-Ilan, A., Goren, A. and Brener, S 1991. Annual variations of air-borne pollen in the coastal plain of Israel. Grana 30, 477-80.

Kloner, A. 2001-2. Water cisterns in Idumea, Judaea and Nabatea in the Hellenistic and Roman Periods. Aram 14, 461-485.

Lebreton, V., Messager, E., Marquer, L. and Renault-Miskovsky, J. 2010. A neotaphonomic experiment in pollen oxidation and its implications for archaeopalynology. Review of Palaeobotany and Palynology 162, 29-38.

Leibner, U. 2009 . Settlement and History in Hellenistic, Roman, and Byzantine Galilee: An Archaeological Survey of the Eastern Galilee. Text and Studies on Ancient Judaism 127. Tübingen: Mohr Siebeck.

Leroy, S. A. G. 2010. Pollen analysis of core DS7-1SC (Dead Sea) showing intertwined effects of climatic change and human activities in the late Holocene. Journal of Archaeological Science 37, 306-16.

Litt, T., Ohlwein, C., Neumann, F. H., Hense, A and Stein, M. 2012. Holocene climate variability in the Levant from the Dead Sea pollen record. Quaternary Science Reviews 49, 95-105.

Loffreda, S. 2008. Cafarnao VII: Documentazione Graficadella Ceramica (1968-2003). Studium Biblicum Franciscanum, Collectio Maior 49, Jerusalem: Edizioni Terra Santa.

Meyers, E. M., Strange, J. F. and Meyers, C. L. 1981. Excavations at Ancient Meiron, Upper Galilee, Israel 1971-72, 1974-75, 1977. Publications of the Meiron Excavation Project 3, Cambridge, Mass.: American Schools of Oriental Research.

Michelson, H., Flexer, A. and Erez, Z 1987. A comparison of the eastern and western sides of the Sea of Galilee and its implication on the tectonics of the Northern Jordan Rift Valley. Tectonophysics 141, 125-34.

Münger, S., Pakkala, J. and Zangenberg, J. K. 2009. Tel Kinrot, Horvat Kur: Kinneret Regional Project - The 2008 Season. Hadashot Arqeologiot/Excavations and Surveys in Israel 121. Available from: http://www.hadashotesi.org.il/report_detai 1 eng .asp?id $=1080 \& \mathrm{mag}$ id $=115$.

Munsell Color 1994. Munsell Soil Color Charts. New Windsor: Macbeth Division of Kollmorgen Instruments.

Neumann, F. H., Kagan, E. J., Schwab, M. J. and Stein, M. 2007a. Palynology, sedimentology and palaeoecology of the Late Holocene Dead Sea. Quaternary Science Reviews 26, 1476-98.

Neumann, F. H., Schölzel, C., Litt, T., Hense, A. and Stein, M. 2007b. Holocene vegetation and climate history of the Northern Golan Heights (Near East). Vegetation History and Archaeobotany 16, 329-46.

Neumann, F. H., Kagan, E. J., Stein, M. and Agnon, A. 2009. Assessment of the effect of earthquake activity on regional vegetation - high-resolutionpollen study of the Ein Feshka section, Holocene Dead Sea. Review of Palaeobotany and Palynology 155, 42-51

Neumann, F. H., Kagan, E. J. and Stein, M. 2010a. Eine Region der Extreme. Umwelt und Klimaveränderungen am Toten Meer, pp. 11-26 in Zangenberg, J. K. (ed.), Das Tote Meer. Kultur und Geschichte am tiefsten Punkt der Erde. Mainz am Rhein: Zaberns Bildbände zur Archäologie.

Neumann, F. H., Kagan, E. J., Leroy, S. and Baruch, U. 2010 b. Vegetation history and climate fluctuations on a transect along the Dead Sea West Shore and their impact on past societies over the last 3500 years. Journal of Arid Environments 74, 7, 756-64.

Porath, Y. 1989. Hydraulic plaster of Aquaeducts as a chronological indicator, pp. 69-76 in Amit, D., Hirschfeld, Y. and Patrich, J. (ed.), The Aquaeducts of Ancient Palestine. Jerusalem: Yad Yitzhak Ben-Zvi.

Reille, M. 1990. Lecons de Palynologie et d'Analyse Pollinique. Paris: Editions du Centre Nacional de la Recherche Scientifique (CNRS).

Reille, M. 1992. Pollen et Spores d' Europe et d'Afrique du Nord. In: Laboratoire de Botanique Historique et Palynologie. Marseille: URA CNRS.

Reille, M. 1995. Pollen et Spores d' Europe et d'Afrique du Nord. Suppl. 1. In: Laboratoire de Botanique Historique et Palynologie. Marseille: URA CNRS.

Reille, M. 1998. Pollen et Spores d' Europe et d'Afrique du Nord. Suppl. 2. In: Laboratoire de Botanique Historique et Palynologie. Marseille: URA CNRS.

Ritterspach, A. D. 1974. The Meiron cistern pottery. Bulletin of the American Schools of Oriental Research 215, 19-30.

Schachtschabel, P., Blume, H.-P., Brümmer, G., Hartge, K.-H. and Schwertmann, U. 1992. Lehrbuch der Bodenkunde (13th edition). Stuttgart: Ferdinand Enke Verlag.

Schwab, M. J., Neumann, F., Litt, T., Negendank, J. F. W. and Stein, M. 2004. Holocene palaeoecology of the Golan Heights (Near East): investigation of lacustrine sediments from Birkat Ram crater lake. Quaternary Science Reviews 23, 1723-31. 
Shivti'el, Y. 2009. Rock Shelters and Hiding Complexes in the Galilee. The History of the Jewish Settlement in the Galilee during the Early Roman Period Based on a Study of Rock-Cut Caves. Unpublished PhD. thesis, Bar-Ilan University, RamatGan.

Stobbe, A. 2009. Ein römischer Brunnen im freien Germanien. Archäologie in Deutschland 2, 28-9.

Stockmarr, J. 1971. Tablets with spores used in absolute pollen analysis. Pollen et Spores 13, 615-21.

Tel-Zur, N. and Schneider, B. A. 2009. Floral Biology of Ziziphus mauritiana (Rhamnaceae). Sex Plant Reproduction 22, 73-85.

Tsafrir, Y. and Foerster, G. 1992. The dating of the 'Earthquake of the Sabbatical Year of 749 C. E.' in Palestine. Bulletin of the School of Oriental and African Studies of London 55, 231-5.

Schoenwetter, J. and Geyer, P. S. 2000. Implications of Archaeological Palynology at Bethsaida, Israel. Journal of Field Archaeology 27, 1, 63-73.

Senior, L. M. and Birnie, D. P., III 1995. Estimating vessel volume from profile illustrations. American Journal of Archaeology 60, 319-34.

Sneh, A. 2008. Geological Map of Israel 1:50000, Tverya: Sheet 4-II. Jerusalem: State of Israel, Ministry of National Infrastructures, Geological Survey of Israel.

Sneh, A., Bartov, Y. and Rosensaft, M. 1998. Geological Map of Israel 1:200,000, Sheet 1. Jerusalem: State of Israel, Ministry of National Infrastructures, Geological Survey of Israel.

Van Geel, B., Buurman, J., Brinkkemper, O., Schelvis, J., Aptroot, A., van Reenen, G. and Hakbijl, T. 2003. Environmental reconstruction of a Roman Period settlement site in Uitgeest (The Netherlands), with special reference to coprophilous fungi. Journal of Archaeological Science 30, 873-83.

Van Haaster, H. 2009. Pollen aus Brunnen und Viehtränken. Archäologie in Deutschland 2, 34-5.

Van Zeist, W., Baruch, U. and Bottema, S. 2009. Holocene palaeoecology of the Hula Area, Northeastern Israel, ppp. 29-64 in Kaptijn, E. and Petit, L. P. (eds.), A Timeless Vale. Archaeological and Related Essays on the Jordan Valley in Honour of Gerrit van der Kooij on the Occasion of his SixtyFifth Birthday. Leiden: Leiden University Press.
Warnock, P. and Pendleton, M. 1995. Appendix B: Amurca, pp. 104-5 in Kanellopoulos, C. (ed.), The great temple of Amman: the architecture. Amman: American Center of Oriental Research

Weinstein-Evron, M. 1994. Biases in archaeological pollen assemblages: Case Studies from Israel, pp. 193-205 in Davies, O. K. (ed.), Aspects of Archaeological Palynology: Methodology and Applications. American Association of Stratigraphic Palynologists Contribution Series 29, Houston, Texas: American Association of Stratigraphic Palynologists Foundation.

Weinstein-Evron, M. and Chaim, S. 1989. Palynology and archaeology: two case studies of submerged archaeological sites in Israel, pp. 23-9 in Spanier, E., Steinberger, Y. and Luria, M. (eds.), Environmental Quality and Ecosystem Stability IV-B. Jerusalem: ISEEQS Publication.

Wood, G. D., Gabriel, A. M. and Lawson, J. C. 1996. Palynological techniques-processing and microscopy, pp. 29-50 in Jansonius, J. and McGregor, D. C. (eds.), Palynology: Principles and Applications 1. Houston, Texas: AASP Foundation.

Yair, A. and Garti, R. 2003. The water supply of the ancient city of Arad, pp. 127-38 in Amiran, R. and Ilan, O. (eds.), Early Arad, the Chalcolithic and Early Bronze IB settlements. Jerusalem: The Israel Exploration Society.

Zangenberg, J. K. 2010. Archaeological news from the Galilee: Tiberias, Magdala and rural Galilee. Early Christianity 1(3), 471-84.

Zangenberg, J. K., Münger, S. and Hakola, R. 2010. Erneut antike Synagoge am See Gennesaret entdeckt. Welt und Umwelt der Bibel 4, 62-3.

Zangenberg, J. K., Bonnie, R., Hakola, R., Münger, S., Petit, L. P. and García Sánchez, J. 2011. Kinneret Regional Project - The 2010 Season. Hadashot Arqeologiot/Excavations and Surveys in Israel 123. Available from: http://www.hadashot-esi.org.il/ report_detail_eng.asp?id $=1746 \&$ mag_id $=118$.

Zohary, M. 1962. The Plant Life of Palestine (Israel and Jordan). Chronica Botanica, N.S. 33. New York: The Ronald Press Co.

Zohary, M. 1982. Vegetation of Israel and Adjacent Areas. Beihefte zum Tübinger Atlas des Vorderen Orients A7. Wiesbaden: Ludwig Reichert Verlag. 